\title{
Developing Vocational Skills for Children of Intellectual Disabilities
}

\author{
Triyanto Pristiwaluyo \\ Special Education Department at State University of Makassar \\ Makassar, Indonesia \\ E-mail: mastrie_mr@yahoo.com
}

\begin{abstract}
Education for children with intellectual disabilities in Indonesia can be held together with other children in regular schools that conduct inclusive education or undertaken independently in special schools. If it is held in public schools it shall use a modified curriculum adapted to the character and potential of those children. If it is held in special schools it shall use a curriculum that specifically designed based on individualized competency standards which is compiled and defined by schools based on the results of assessment. The education for children with intellectual disabilities is more focused on development of vocational skills than development of intellectual skills. The goal is for those children to be able to live independently and have vocational skills to live in the community. So far, the curriculum used for children with intellectual disabilities could not fully accommodate their needs to be able to live independently because it currently uses a modified regular curriculum. To have adequate vocational skills, their education needs to be conducted continuously, focused on a certain set of skills, and implemented through an internship program in sheltered workshops. By having a specifically designed educational service, children with intellectual disabilities could develop their skills optimally.
\end{abstract}

Keywords:

children with intellectual disabilities, vocational skills, independency

\section{INTRODUCTION}

Self-care activities such as eating, drinking, bathing, decorating, washing both dishes and clothes as well as daily routine can easily be done by normal children in general, but not for children with intellectual disability. Children with intellectual disabilities need special guidance and direction from those around them, in order to master the simple faculties required in the activities of daily life. Education for normal children is directed to the development of intellectual ability whereas mild-intellectual disability of children education is directed to the development of self-care skills provide skills to be selfsufficient.

Law number 20 of 2003 on the National Education System ensures all citizens have equal rights to obtain educational services, including children . In Indonesia, education for children with intellectual disabilities can be carried out coincided with children in general in regular schools that provide inclusive education or undertaken independently at Special Schools. The purpose of education for children with intellectual disabilities is to be able to take care of them and has vocational skills as a provision to meet the needs of children's circumstances.

\section{DEFINITION AND TERM OF INTELLECTUAL DISABILITY}

There are a number of terms that have been used to label children with mental retardation, such as by Hilliard \& Kirman (Smith, et. al, 2002: 43).

People who are mentally retarded over time have been referred to as dumb, stupid, immature, defective, deficient, subnormal, incompetent, and dull. Terms such as idiot, imbecile, moron, and feebleminded were commonly used historically to label this population. Although the word fool referred to those who were mentally ill, and the word idiot was directed toward individuals who were severely retarded, these terms were frequently used interchangeably.

From some of these terms the most popularly used in Indonesia are mentally retarded. In 1992 Ruth Luckasson (Smith 
et.al., 2002) once put forward the definition made by the American Association on Mental Retardation (AAMR): as follows:

Mental retardation "refers to substantial limitations in present functioning. It is characterized by significantly subaverage intellectual functioning, existing concurrently with related limitations in two or more of the following applicable adaptive skill areas: communication, selfcare, home living, social skills, community use, self-direction, health and safety, functional academics, leisure and work. Mental retardation manifests before age 18."

The definition of AAMR is the basis for identifying individual who is considered the category of mental retardation. Individuals are considered mentally retarded if they meet the two criteria proposed by AAMR, namely intellectual impairment and short comings in adaptive behavior. Backwardness or deficiency in adaptation behavior with its environment is measured by the level of calendar age that a person has achieved.

Today, in Indonesia the term mentally retarded is no longer used in official state documents. Schools and governmental institutions use the term "mentally retarded". The term mentally retarded is defined to describe children with intellectual and developmental disabilities. Schalock et al., 2010 (Kauffman \& Hallahan, 2011: 176) sets forth the limits released by the American Association on Intellectual and Developmental Disabilities (AAIDD) which state that disability is characterized by significant limitations in intellectual function and adaptive behavior shown in adaptation skills conceptually, socially, and practically. These impairment occur before 18 years old.

On the other hand Mupuniarti (2005) states that children with intellectual impairment are children who are substantially experiencing impairment and intellectual development far below the average with difficulty to adapt in social life significantly.

From some opinions, it is implied that children with intellectual disabilities are characterized by intellectual impairment and developments well below the average normal child, experiencing backwardness or deficiency in behavioral adaptation to the environment, and occurring within a period of development (before 18 years old).

Based on the intensity of intellectual impairment and adaptive behavior, children with intellectual disabilities are classified into three categories: mild, moderate and severe. According Mumpuniarti (2005) children mild intellectual disabilities is able to work at semiskilled jobs, children with moderate intellectual disabilities being able to work in sheltered workshops or work for routine work under supervision, while severe and profound are always depend on the care and help of others. This condition has implications for their vocational education programs.

When entering adulthood, individuals with intellectual disabilities, biologically needs sexuality that is also growing. They will also be nurtured by families like members of society at large. They are also required to meet the needs of family life. However, to meet this need is not as easy as a normal child in general. Therefore, when they come into a period of transition to adult age that need specially prepared their career development, in order to live in the community well.

\section{EDUCATIONAL OF CHILDREN WITH INTELLECTUAL DISABILITIES}

\subsection{Special Education Curriculum for Intellectual Disablities Students}

Children with intellectual disabilities have limitations on their intellectual function. Therefore their educational programs are continued to develop non-academic competency. Their education is more focused on developing the competency of vocational skills.

Education for children with intellectual disabilities in Indonesia can be undertaken with other children in regular schools that conduct inclusive education or are undertaken independently in special schools (SLB). Derived from Permendikbud No. 157 year 2014, curriculum for students with special needs might be implemented in the form of curriculum of regular education or special education curriculum. Learning of students with special needs are developed based on the results of the students' assessment, referring to the principles and regular learning approaches tailored to the learning characteristics and uniqueness of each disabled students. Disabled students are those who have difficulty in the learning process because of physical, 
emotional, mental, intellectual, and/ or social abnormalities; and/or gifted students who have potential intelligence and/or special talents.

Furthermore, students with special needs who are not accompanied by intellectual impairment, communication and interaction, and behavior can follow the curriculum of regular education 2013. Although they do not experience in any aspect of impairment, they still need special education services. To students with intellectual impairment, communication and interaction, and behavior are provided with special educational curricula. Special educational curricula for disabled students are included general programs, special needs programs, and independence programs.
In essence, the special education curriculum is for students with intellectual disabilities. In the Curriculum Technical Instructions 2013 for Basic Education, Special Education disclosed that the special educational curricula for students experiencing intellectual disabilities is developed by modifying the regular curriculum, by simplifying or lowering the level of achievement of the competency standard of learners equivalent to meet that need, the regular curriculum can be added to a special needs program. For special needs the regular curriculum of grade IV or one-third of the competency standard of the regular learners.

The equivalence of regular curricula and special education curricula can be summarized as follows.

\section{Kesetaraan Kurikulum Reguler-Tuna Grahita}

\begin{tabular}{|c|c|}
\hline Tuna Grahita & Reguler \\
\hline Kelas I & Kelas I \\
\hline Kelas II & \\
\hline Kelas III & IS III \\
\hline Kelas IV & s IV \\
\hline Kelas V & Kelas V \\
\hline Kelas VI & Kelas VI \\
\hline Kelas VII & Kelas VII \\
\hline Kelas VIII & Kelas VIII \\
\hline Kelas IX & Kelas IX \\
\hline Kelas $\mathbf{X}$ & Kelas $\mathbf{X}$ \\
\hline Kelas XI & Kelas XI \\
\hline Kelas XII & Kelas XII \\
\hline
\end{tabular}

figure 1. The Equality of the Curriculum

figure 1 shows that the curriculum content of special education for learners of intellectual disability and autism class I SDLB / MILB up to class XII SMALB / MALB equal to the content of curriculum of regular education up to class IV SD / MI plus special needs program and independency choice program.

The hallmark of education for children with intellectual disabilities is more about developing the skills of vocational competence than the development of intellectual ability. The goal is to be independent and have vocational skills as a provision to meet the needs of their life.

\begin{tabular}{|l|l|l|}
\hline Kekhususan & Kemampuan & Kesetaraan \\
\hline Autis & $1 / 2$ & $\begin{array}{l}\text { SD : } 1-3 \\
\text { SMP: } 4-5\end{array}$ \\
\hline Daksa & $2 / 3-3 / 4$ & $\begin{array}{l}\text { SD : } 1-4 \\
\text { SMP: } 5-6\end{array}$ \\
\hline Netra & $2 / 3-3 / 4$ & $\begin{array}{l}\text { SD : } 1-4 \\
\text { SMP: } 5-6\end{array}$ \\
\hline Rungu & $1 / 2-2 / 3$ & SD : $1-3$ \\
& & SMP: $4-6$ \\
\hline
\end{tabular}

During this time, the special curriculum has not fully accommodated the needs of students' independence of intellectual disabilities. While the reality of the field shows that there are still many students with intellectual disabilities after completing education in school, not yet has the skills to be able to work independently. According to Astati (2009) children with special needs do not have skills that can be used by the business, because the school does not prepare skill development program that is in line with the business world. Alimin (2007) stated that the educational program for intellectual disabilities students is still much stressed throughout academic aspects of teaching. Actually the education required by students' intellectual disabilities are education that emphasizes on education that is functional. 
This means that an educational approach to the needs of the child is not emphasized on the curriculum orientation. Then it is expected that children after learning can have the skills to be able to live independently.

\subsection{Learning Program for Intellectual Disabilities Students}

There are different problems for intellectual impaired students in registering the workforce. In addition, physical, mental, emotional and/ or social limitations lead also to the constraint in work skills that are appropriate to demands of the business and the industrial world. Therefore, for students with special needs in special schools (SLB) and those who study inclusively in regular schools, they need to be prepared for vocational skills early, systematically and programmatically. Vocational learning programs are implemented in a tiered and continuous manner. At the early childhood level, students are explored through play, at the elementary level developed a simple literacy skills, at the junior high level of vocational learning reaches $60 \%$ and at high school vocational learning achieves $70 \%$ more than academic learning. Between students who one with another may pursue different types of skills, but they still study the same subjects even though the material is different. At the secondary level (junior and senior high school) students should be grouped based on the skill class, not the academic class.

So at the junior and senior high school level, for example their class will be in the form of Culinary Class, Clothing Class, Automotive Class and so forth according to the type of skill that is in demand. Academic learning in intellectual disabilities students, more directed to support vocational learning in accordance with the type of skills of interest. They both studied mathematics, but the culinary art class for instance has the materials around calculating the price of onion to be purchased to cook rendang. While in the clothing class, the materials are still around calculating the size of the sleeve that will be sewn.

According to Kirono (2013) the learning of vocational skills given to this intellectual disabilities students is of course adapted to his abilities. If the condition of the child allows to study that all the stages of a skill, there is no harm in all the stages are given to him, but if the condition is not possible then it is enough to learn one or two parts of the stage of a skill. For example in the skill of making slippers, if the conditions allow intellectual disabilities children are entitled to learn all the stages in making slippers. However, if the condition is not possible, then he is enough to learn one or two stages only for example only glued or glue it.

Smart (Kirono, 2013) suggests that skills are also very important given to those with special needs. From these skills, they can find the talent that exists within them, such as handicrafts. If there is a visible talent, the talent needs to be developed and given appreciation. In this way, it is expected that they have a busy life and if the craft they produce has the selling power, it will be an asset for them. Thus vocational skills education can be considered as the stage of career preparation for intellectual impaired children to play a role in the family as well as in society. In line with the expected Division on Career Development and Transition of the Council for Exceptional Children (Smith, et al., 2002: 411) stating that "career development involves the preparation of the individual for the roles of the student, worker, family member, and citizen.

For children with mild intellectual disabilities, the opportunity to gain open employment is wider because they can be provided with vocational skills training covering many areas such as housekeeping skills, carpentry skills, farming and livestock skills, office skills, marketing skills, entrepreneurship, and other skills Semi-skilled. For children with moderate intellectual disabilities, although the skills that can be learned are more limited, but do not close their chances to be able to work and live independently. They can learn household skills to be able to work at home, or to perform a simple skill that can be channeled to a sheltered workshop. In addition, children with intellectual disabilities can still work in certain agencies, although doing something simple and requires supervision.

Implementation of vocational skills education needs to involve stakeholders amid teachers, governments, parents, and jobs. Cooperation is needed to formulate the types of skills, methods and strategies that can be applied to children with special needs (Astati, 2009). With vocational educational training suitable for children intellectual disorders should be perpetuated constantly. In order for the child's intellectual disabilities to have adequate vocational skills, vocational skills 
education should be done continuously, with the type of focused skills, and practiced directly in the workplace. By getting special educational services, it is expected that the child's intellectual disabilities can develop optimally, ready to plunge in the community.

\section{REFERENCES}

[1] Alimin, Z., Melakukan Orientasi Ulang tentang Pendidikan bagi Peserta Didik Tunagrahita, [On line]. Tersedia:http://www.jasianakkusampel.blogspot.-com//, [6 Pebruari 2011].

[2] Alimin, Z., (2006), Orientasi ulang pendidikan bagi peserta didik tunagrahita dari pendekatan formal ke pendekatan fungsional. Jakarta: UPI.

[3] Amin, M, (1996), Orthopedagogiek Anak Tunagrahita, Jakarta, Depdikbud Dirjen Dikti.

[4] Astati, Pendidikan Vokasional, [On line]. Tersedia: http:/file.upi.edu/Direktori/A FIP/Jur. Pend. Luar Biasa/,[6 Pebruari 2011].

[5] Grant, Gordon., Goward, Peter., Richardson, Malcolm., and Ramcharan, Paul., (2005), Learning Disability : A life cycle approach to valuing people.,
McGraw-Hill New York: Open University Press.

[6] Kauffman, James M., Hallahan, Daniel P., (2011), Handbook of special education. New York : Routledge Group.

[7] Kementerian Pendidikan dan Kebudayaan, Peraturan Menteri Pendidikan dan Kebudayaan Republik Indonesia Nomor 157 Tahun 2014 Tentang Kurikulum Pendidikan Khusus, Jakarta, 2014.

[8] Kementerian Pendidikan dan Kebudayaan, Petunjuk Teknis Kurikulum 2013 Untuk Pendidikan Dasar Pendidikan Khusus, Jakarta, 2014.

[9] Kirk, S.A. \& Gllagher, J.J., (1989), Educating exceptional children. Boston: Houghton Mifflin Company.

[10]Kirono, Rejo., (2013), Model Manajemen Pendidikan Keterampilan Di SMALB untuk Menyiapkan Anak Tunagrahita Ringan Memasuki Dunia Kerja.,disajikan dalam Seminar Pendidikan APPKhI DIY., Yogyakarta.

[11] Mumpuniarti, (2006), Manajemen Pembinaan Vokasional Bagi Tunagrahita di Sekolah Khusus Tunagrahita. Jurnal Pendidikan Khusus Vol 2 No.2, Nopember 2006. Yogyakarta: Jurusan PLB UNY,.

[12] Smith, M. B., Ittenbach, R. F. \& Patton, J. R., (2002), Mental retardation. 6th ed. New Jersey: Merrill Prentice Hall. 